\title{
Hypocrellin D, a Cytotoxic Fungal Pigment from Fruiting Bodies of the Ascomycete Shiraia bambusicola
}

\author{
Li-Zhen Fang, Chen Qing, Hong-Jun Shao, Yi-Dong Yang, Ze-Jun Dong, Fei Wang, \\ Wei Zhao, Wan-Qiu Yang, Ji-Kai Liu
}

Received: April 18, 2006 / Accepted: May 25, 2006

(C) Japan Antibiotics Research Association

\begin{abstract}
A fungal pigment, hypocrellin D (1), together with three known perylenequinone derivatives hypocrellin A (2), B (3) and C (4), was isolated from the fruiting bodies of Shiraia bambusicola. Its structure was elucidated on the basis of spectral data including 2D NMR experiments. Hypocrellin D (1) significantly inhibited the growth of tumor cell lines Bel-7721, A-549 and Anip-973 with $\mathrm{IC}_{50}$ values of $1.8,8.8,38.4 \mu \mathrm{g} / \mathrm{ml}$, respectively.
\end{abstract}

Keywords hypocrellin D, perylenequinone, Shiraia bambusicola, pigment, ascomycete, cytotoxicity

\section{Introduction}

Shiraia bambusicola P. Hennigs (Hypocreaceae), an ascomycete parasitic on bamboo twigs, is recorded only in China and Japan. It has been commonly used as medicinal fungi under the name of "Zhu Huang" in China for treatment of rheumatism and pneusomia in traditional Chinese medicine (TCM) [1]. Previously new perylenequinone pigments hypocrellin $\mathrm{A} \sim \mathrm{C}$ and shiraiachrome $\mathrm{A} \sim \mathrm{C}$ have been isolated from $S$. bambusaicola as fungal metabolites which exert photodynamic activity towards bacteria and fungi $[2,3]$. Lately the methanolic extract of the mycelium of the fungus $S$. bambusicola was found to show significant cytotoxicity in the A-549 and HCT-8 solid tumor cells. Subsequent bioassay-guided fractionation in HCT-8 in vitro

J.-K. Liu (Corresponding author), L.-Z. Fang, H.-J. Shao, Z.-J. Dong, Fei Wang, W.-Q. Yang, J.-K. Liu: State Key Laboratory of Phytochemistry and Plant Resource in West China, Kunming Institute of Botany, Chinese Academy of Sciences, Kunming 650204, China, E-mail: jkliu@mail.kib.ac.cn led to the isolation and characterization of shiraiachromes $\mathrm{A}$ and $\mathrm{B}$ as two major cytotoxic principles [4]. A series of new perylene derivatives related to shiraiachrome-A and -B as well as calphostin-C have been synthesized and evaluated for their cytotoxicities, antiviral activities, and inhibitory activities against protein kinase C [4]. In our continual investigation of the bioactive metabolites from higher fungi [5 9], a pigment, named hypocrellin D (1), was isolated from S. bambusaicola, together with hypocrellins A (2), B (3) and C (4). This report deals with the isolation, structural elucidation and cytotoxic activity of hypocrellin D (1).

\section{Materials and Methods}

\section{General}

Melting points were determined by the micro hot-plate method and are uncorrected. Optical rotations were measured on a Horiba SEPA-300 polarimeter. IR spectra were obtained with a Tensor 27 with $\mathrm{KBr}$ pellets. UV spectra were recorded on a Shimadzu UV-2411 PC spectrophotometer. NMR spectra were recorded on Bruker AV-400 and Bruker DRX-500 spectrometers in $\mathrm{CDCl}_{3}$ solvent with TMS as an internal standard. EI-MS were recorded with a VG Autospec-3000 spectrometer. ESI-MS and HRESI-MS were recorded with an API QSTAR Pulsar I spectrometer.

C. Qing, Y.-D. Yang, W. Zhao: Kunming Medical College, Kunming 650031, China

L.-Z. Fang: Graduate School of the Chinese Academy of Sciences, Beijing 1000439, China 
Silica gel (200 300 mesh, Qingdao Marine Chemical Inc., China) and Sephadex LH-20 (Amersham Bioscience, Sweden) were used for column chromatography. Preparative TLC was performed on glass plates with silica gel $60 \mathrm{~F}_{254}$ (Qingdao Marine Chemical Inc., China). Fractions were monitored by TLC and spots were visualized by heating silica gel plates sprayed with $10 \% \mathrm{H}_{2} \mathrm{SO}_{4}$ in ethanol.

\section{Mushroom Material}

The fresh fruiting bodies of $S$. bambusicola were collected in Shangri-La of Yunnan Province, China, in July 2004. The voucher specimen was deposited at the Herbarium of Kunming Institute of Botany, the Chinese Academy of Sciences.

\section{Extraction and Isolation}

Fruiting bodies of $S$. bambusicola $(1.5 \mathrm{~kg})$ were pulverized and extracted with $\mathrm{CHCl}_{3} / \mathrm{CH}_{3} \mathrm{OH}(1: 1, \mathrm{v} / \mathrm{v})$ six times at room temperature. The combined extracts were concentrated in vacuo to give syrup. The syrup $(87 \mathrm{~g})$ was subjected to silica gel column chromatography employing a gradient elution with $\mathrm{CHCl}_{3} / \mathrm{CH}_{3} \mathrm{OH}(100: 0$ to $50: 100, \mathrm{v} / \mathrm{v})$ to give five fractions. Fractions II $(163.3 \mathrm{mg})$, eluted with $\mathrm{CHCl}_{3} / \mathrm{CH}_{3} \mathrm{OH}(100: 0$ to $100: 10, \mathrm{v} / \mathrm{v})$, was separated by preparative TLC with petroleum ether/acetone $(3: 2, \mathrm{v} / \mathrm{v})$ and purified on Sephadex LH-20 with acetone to afford $1(15.5 \mathrm{mg})$ and a dark red mixture. The mixture was further separated by repeated preparative TLC with $\mathrm{CHCl}_{3} / \mathrm{CH}_{3} \mathrm{OH}(9: 1, \mathrm{v} / \mathrm{v})$ to yield $\mathbf{2}(42.3 \mathrm{mg}), 3$ (21.5 mg), and 4 (19.6 mg).

\section{Physico-chemical Properties}

Hypocrellin D (1): orange-red crystal, m.p. $109 \sim 110^{\circ} \mathrm{C}$ (acetone), $[\alpha]_{\mathrm{D}}^{20}+2465.9$ (c 0.71 , acetone). UV $\lambda_{\max }^{\mathrm{CHCl}_{3}} \mathrm{~nm}$ (c) 438 (6,725), 293 (22,729), 254.5 (19,223), 239.5 $(21,913)$. IR (KBr) 3453, $1633 \mathrm{~cm}^{-1}$. EI-MS $m / z 578(\mathrm{M}$, 18), $563\left(\mathrm{M}-\mathrm{CH}_{3}, 2\right), 546\left(\mathrm{M}-\mathrm{CH}_{3}-\mathrm{OH}, 14\right), 521$ (21), 503 (15), 487 (8), 479 (47), 461 (20), 447(9), 419 (8), 368 (6), 321 (7), 307 (8), 281 (10), 265 (12), 236 (9), 221 (15), 181 (15), 169 (16), 149 (55), 131 (28), 111 (44), 97 (59), 83 (70), 69 (98), 57 (100) $\mathrm{cm}^{-1}$. HRESI-MS $\mathrm{m} / z 601.1331$ $\left(\mathrm{M}+\mathrm{Na}\right.$, Calcd. for $\left.\mathrm{C}_{30} \mathrm{H}_{26} \mathrm{O}_{12} \mathrm{Na} 601.1321\right)$.

\section{Cell Lines and Culture}

All cell lines were grown in RPMI-1640 medium (GIBCO) supplemented with $10 \%$ heat-inactivated bovine serum, $2 \mathrm{nM}$ L-glutamine, $10^{5} \mathrm{IU} /$ liter penicillin $\mathrm{G}, 100 \mathrm{mg} /$ liter streptomycin and $10 \mathrm{mM}$ HEPES, pH 7.4. Cells were kept at $37^{\circ} \mathrm{C}$ in a humidified $5 \% \mathrm{CO}_{2}$ incubator.

\section{Cell Growth Inhibition Assay}

Growth inhibition of hypocrellin D (1) on tumor cells was measured by the microculture [3-(4,5-dimethylthiazol-2yl)-2,5-diphenyl-tetrazolium bromide (MTT) assay $[10,11]$ with minor modification [12]. Briefly, adherent tumor cells were seeded into 96-well microculture plates and allowed to adhere for 24 hours before drug addition, while suspended cells were seeded just before drug addition. Each tumor cell line was exposed to compound at 0.01 , $0.1,1,10,100 \mu \mathrm{g} / \mathrm{ml}$ concentrations for different periods (adhere cells for 72 hours, suspended cells for 48 hours) and each concentration was tested in triplicate. At the end of exposure, $20 \mu \mathrm{l}$ of $5 \mathrm{~g} /$ liter MTT (Sigma Chemical Co.) was added to each well and the plates were incubated for 4 hours at $37^{\circ} \mathrm{C}$, then "triplex solution $(10 \%$ SDS - 5\% isobutanol $-0.012 \mathrm{M} \mathrm{HCl}$ )" was added and the plates were incubated for $12 \sim 20$ hours at $37^{\circ} \mathrm{C}$. The optical density (OD) was read on a plate reader at a wavelength of $570 \mathrm{~nm}$. Media and DMSO control wells, in which 1 was absent, were included in all the experiments in order to eliminate the influence of DMSO. The inhibitory rate of cell proliferation was calculated by the following formula:

$$
\begin{aligned}
& \text { Growth inhibition }(\%)= \\
& \quad\left[\mathrm{OD}_{\text {control }}-\mathrm{OD}_{\text {treated }} / \mathrm{OD}_{\text {control }}\right] \times 100 \%
\end{aligned}
$$

The cytotoxicity of $\mathbf{1}$ on tumor cells was expressed as $\mathrm{IC}_{50}$ values and was calculated by LOGIT method.

\section{Results and Discussion}

Compounds 2, 3 and $\mathbf{4}$ were obtained as dark red crystals with metallic luster and displayed molecular (EI-MS) ion at $\mathrm{m} / \mathrm{z} 546,546$ and 528, which were in agreement with molecular formula $\mathrm{C}_{30} \mathrm{H}_{26} \mathrm{O}_{10}, \mathrm{C}_{30} \mathrm{H}_{26} \mathrm{O}_{10}$ and $\mathrm{C}_{30} \mathrm{H}_{24} \mathrm{O}_{9}$, respectively. These compounds were determined to be hypocrellins $\mathrm{A}, \mathrm{B}$ and $\mathrm{C}$ by comparing the ${ }^{1} \mathrm{H}$ - and ${ }^{13} \mathrm{C}$ NMR spectral data with those of hypocrellins in literature [2]. The relative configuration of hypocrellin A was already confirmed by X-ray analysis [13], and its absolute configuration was also established by comparing its $\mathrm{CD}$ spectrum with those of isocercisporin and cercisporin [2, $14,15]$. The axial chirality of 2 is $P(S)$, and the absolute configurations at $\mathrm{C}-14$ and $\mathrm{C}-15$ of 2 are $S$ and $R$, respectively (Fig. 1).

Compound 1 was obtained as orange-red crystals. The molecular formula of $\mathbf{1}$ was determined to be $\mathrm{C}_{30} \mathrm{H}_{26} \mathrm{O}_{12}$ on the basis of HR-ESI-MS $m / z$ 601.1331 (M+Na, Calcd. for $\mathrm{C}_{30} \mathrm{H}_{26} \mathrm{O}_{12} \mathrm{Na}$ 601.1321) and ${ }^{13} \mathrm{C}-\mathrm{NMR}$ spectra (DEPT: six methyls, one methylene, three methines and twenty quaternary carbons). IR spectrum of $\mathbf{1}$ showed absorption 


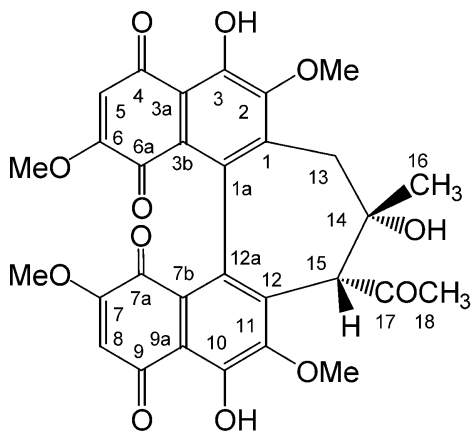

1

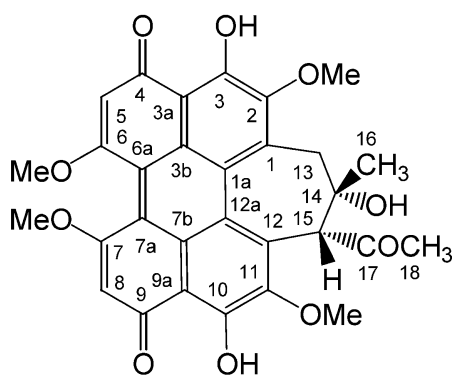

2

Fig. 1 Structures of hypocrellin D (1) and A (2).

Table $1{ }^{1} \mathrm{H}$ - and ${ }^{13} \mathrm{C}-\mathrm{NMR}$ spectra data for $\mathbf{1}$ and $\mathbf{2}$ in $\mathrm{CDCl}_{3}$

\begin{tabular}{|c|c|c|c|c|}
\hline Position & 1 & & 2 & \\
\hline 1 & & 131.7 (s) & & 133.1 (s) \\
\hline $1 a$ & & 135.3 (s) & & $127.7(\mathrm{~s})$ \\
\hline 2 & & 152.0 (s) & & $150.9(\mathrm{~s})^{\mathrm{a}}$ \\
\hline 3 & & 154.6 (s) & & $172.0(\mathrm{~s})^{\mathrm{b}}$ \\
\hline $3 a$ & & 114.7 (s) & & 106.7 (s) \\
\hline $3 b$ & & 124.0 (s) & & $125.0(\mathrm{~s})$ \\
\hline 4 & & 191.3 (s) & & $180.2(\mathrm{~s})^{\mathrm{C}}$ \\
\hline 5 & $6.04(1 \mathrm{H}, \mathrm{s})$ & $108.8(d)$ & $6.53(1 \mathrm{H}, \mathrm{s})$ & $102.0(d)$ \\
\hline 6 & & $161.4(\mathrm{~s})$ & & $167.4(\mathrm{~s})$ \\
\hline $6 a$ & & 179.2 (s) & & $118.1(\mathrm{~s})$ \\
\hline 7 & & $161.1(\mathrm{~s})$ & & $167.4(\mathrm{~s})$ \\
\hline $7 a$ & & 178.9 (s) & & $117.7(\mathrm{~s})$ \\
\hline $7 b$ & & 122.6 (s) & & 125.0 (s) \\
\hline 8 & $6.02(1 \mathrm{H}, \mathrm{s})$ & $108.5(d)$ & $6.59(1 \mathrm{H}, \mathrm{s})$ & $102.0(d)$ \\
\hline 9 & & 191.1 (s) & & $179.7(\mathrm{~s})^{\mathrm{c}}$ \\
\hline $9 a$ & & $115.4(\mathrm{~s})$ & & 106.9 (s) \\
\hline 10 & & 154.5 (s) & & $171.1(\mathrm{~s})^{\mathrm{b}}$ \\
\hline 11 & & 151.6 (s) & & $150.7(\mathrm{~s})^{a}$ \\
\hline 12 & & 134.6 (s) & & $133.9(\mathrm{~s})$ \\
\hline $12 \mathrm{a}$ & & $135.4(s)$ & & $128.6(\mathrm{~s})$ \\
\hline $13 \mathrm{H}^{\mathrm{a}}$ & $3.15(1 \mathrm{H}, \mathrm{d}, 12.6)$ & $38.0(t)$ & $3.52(1 \mathrm{H}, \mathrm{d}, 12.0)$ & $41.9(\mathrm{t})$ \\
\hline $\mathrm{H}^{\mathrm{b}}$ & $1.93(1 \mathrm{H}, \mathrm{d}, 12.6)$ & & $2.63(1 \mathrm{H}, \mathrm{d}, 12.0)$ & \\
\hline 14 & & 78.1 (s) & & 78.7 (s) \\
\hline 15 & $3.02(1 \mathrm{H}, \mathrm{s})$ & $57.8(d)$ & $3.46(1 \mathrm{H}, \mathrm{s})$ & $60.7(d)$ \\
\hline 16 & $1.31(3 \mathrm{H}, \mathrm{s})$ & $26.0(q)$ & $1.70(3 \mathrm{H}, \mathrm{s})$ & $26.9(q)$ \\
\hline 17 & & 207.6 (s) & & 207.5 (s) \\
\hline 18 & $2.09(3 \mathrm{H}, \mathrm{s})$ & $30.6(q)$ & $1.89(3 \mathrm{H}, \mathrm{s})$ & $30.0(q)$ \\
\hline $2-\mathrm{OCH}_{3}$ & $4.07(3 \mathrm{H}, \mathrm{s})$ & $61.3(q)$ & $4.11(3 \mathrm{H}, \mathrm{s})$ & $62.0(q)$ \\
\hline $11-\mathrm{OCH}_{3}$ & $3.90(3 \mathrm{H}, \mathrm{s})$ & $60.9(q)$ & $4.11(3 \mathrm{H}, \mathrm{s})$ & $61.7(q)$ \\
\hline $6-\mathrm{OCH}_{3}$ & $3.81(3 \mathrm{H}, \mathrm{s})$ & $56.6(q)$ & $4.06(3 \mathrm{H}, \mathrm{s})$ & $56.5(q)$ \\
\hline $7-\mathrm{OCH}_{3}$ & $3.80(3 \mathrm{H}, \mathrm{s})$ & $56.6(q)$ & $4.06(3 \mathrm{H}, \mathrm{s})$ & 56.4 (q) \\
\hline $3-\mathrm{OH}$ & $13.19(1 \mathrm{H}, \mathrm{s})$ & & $15.92(1 \mathrm{H}, \mathrm{s})$ & \\
\hline $10-\mathrm{OH}$ & $13.25(1 \mathrm{H}, \mathrm{s})$ & & $15.97(1 \mathrm{H}, \mathrm{s})$ & \\
\hline
\end{tabular}

a, b, c: Assignments in each column may be interchangeable. 


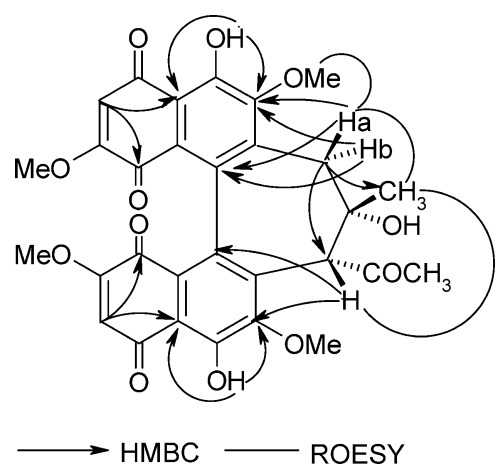

Fig. 2 Key HMBC and ROESY correlations of $\mathbf{1}$.

at $1633 \mathrm{~cm}^{-1}$, which was consistent with the presence of $\mathrm{H}-$ bonded carbonyl groups. The pair of singlet peaks at $\delta$ 13.25 and 13.19 in ${ }^{1} \mathrm{H}-\mathrm{NMR}$ indicated the presence of chelating protons. According to ${ }^{1} \mathrm{H}$ - and ${ }^{13} \mathrm{C}$-NMR spectra, the carbon skeleton of $\mathbf{1}$ was similar to that of hypocrellin A (2). The most distinct differences between $\mathbf{1}$ and $\mathbf{2}$ were that: (a) The signals of two carbons at $\delta 179.2$ and 178.9 of 1 appeared instead of those at $\delta 118.1$ and 117.7 of 2; (b) The carbonyl signals at C-4 and C-9 ( $\delta 180.2$ and 179.7) in 2 markedly shifted downfield ( $\delta 191.3$ and 191.1) in $\mathbf{1}$.

Such changes suggested the presence of conjugated carbonyl groups in $\mathbf{1}$. Remaining signals of ${ }^{1} \mathrm{H}$ - and ${ }^{13} \mathrm{C}$ NMR spectra of $\mathbf{1}$ were consistent with a seven-membered ring, which was similar to that of hypocrellin A (2). To establish the relative stereostructure of $\mathbf{1}$, the ROESY experiment was carried out. Observed correlations between $2-\mathrm{OCH}_{3}$ and $13-\mathrm{Ha}, 13-\mathrm{Ha}$ and $16-\mathrm{CH}_{3}, 16-\mathrm{CH}_{3}$ and $15-\mathrm{H}$ indicated that $13-\mathrm{Ha} 16-\mathrm{CH}_{3}$ and $15-\mathrm{H}$ are cis form.

1 exhibited to possess cytotoxic activities against tumor cell lines, Bel-7721, A-549 and Anip-973, with $\mathrm{IC}_{50}$ values, $1.8,8.8,38.4 \mu \mathrm{g} / \mathrm{ml}$, respectively. It is noted that $\mathbf{1}$ possessing a seco-3b,7b perylenequinone structure is firstly reported from nature though it was already reported as a photochemically converted compound $[16,17]$.

Acknowledgements This project was supported by the National Natural Science Foundation of China (30470027 and 30225048) and Natural Science Foundation of Yunnan Province (2000C0001P).

\section{References}

1. Liu JK. Mycochemistry. pp. 236-237 China Science and Technology Press, Chinese (2004)

2. Wu H, Lao XF, Wang QW, Lu RR. The shiraiachromes: novel fungal perylenequinone pigments from Shiraia bambusicola. J Nat Prod 52: 948-951 (1989)

3. Kishi T, Tahara S, Taniguchi N, Tsuda M, Tanaka C, Takahashi S. New perylenequinones from Shiraia bambusicola. Planta Med 57: 376-379 (1991)

4. Wang HK, Xie JX, Chang JJ, Hwang KM, Liu SY, Lawrence $\mathrm{MB}$, Jing JB, Lee KH. Antitumour agent. 134. new shiriaiachrome-A and calphostin-C-related perylene derivatives as cytotoxic and antiviral agents and inhibitors of protein kinase C. J Med Chem 35: 2721-2727 (1992)

5. Liu JK. N-Containing compounds of Macromycetes. Chem Rev 105: 2723-2744 (2005)

6. Liu JK. Biologically active substances from mushrooms in Yunnan, China. Heterocycles 57: 157-167 (2002)

7. Luo DQ, Wang F, Bian XY, Liu JK. Rufuslactone, a new antifungal sesquiterpene from the fruiting bodies of the basidiomycete Lactarius rufus. J Antibiot 58: 456-459 (2005)

8. Wang F, Luo DQ, Liu JK. Aurovertin E, a new polyene pyrone from basidiomycete Albatrellus confluens. J Antibiot 58: 412-415 (2005)

9. Wang XN, Tan RX, Liu JK. Xylactam, a new nitrogencontaining compound from the fruiting bodies of Ascomycete Xylaria euglossa. J Antibiot 58: 268-270 (2005)

10. Mosmman T. Rapid colorimetric assay for cellular growth and survival: Application to proliferation and cytotoxicity assays. J Immunol Meth 65: 55-63 (1983)

11. Alley MC, Scudiero DA, Monks A, Hursey ML, Czerwinski MJ, Fine DL. Feasibility of drug screening with panels of human tumor cell lines using a microculture tetrazolium assay. Cancer Res 48: 589-601 (1988)

12. Zhou JJ, Yue XF, Han JX, Yang WY. Improved MTT assay for activity of antitumor agents. Chin J Pharm 24: 455-457 (1993)

13. Chen WS, Chen YT, Wan XY, Friedrichs E, Puff H, Breitmaier E. Die struktur des hypocrellins und seines photooxxidationsproduktes peroxyhypocrellin. Liebigs Ann Chem 1880-1885 (1981)

14. Arnone A, Camarda L, Nashini G, Merlini L. Secondary mould metabolites. part 13. fungal perylenequinones: phleichrome, isophleichrome, and their endoperoxides. J Chem Soc Perkin Trans I. 1387-1392 (1985)

15. Nasini G, Merlini L, Andreetti GD, Bocelli G, Sgarabotto P. Stereochemistry of cercosporin. Tetrahedron 38: 2787-2796 (1982)

16. Zhao KH, Jiang LJ. Photochemical properties of hypocrellin A, B and their oxides. Chinese J Chem 8: 55-60 (1990)

17. Diwu Z, Lown JW. Perylenequinonoid pigments as potential photodynamic therapeutic agents: Formation of semiquinone radicals and reactive oxygen species on illumination. J Photochem Photobiol B 18: 131-143 (1993) 